\title{
Disabled Citizens: A Case Study of Pakistan
}

\author{
Khalid Salahuddin and Amanat Ali Jalbani \\ SZABIST Karachi
}

\begin{abstract}
Destiny is divine governed. Nobody knows what happens tomorrow. We live in emerging era of fast tract life focusing to achieve targets in the shortest possible time. In this mechanized world we forget those who due to some reason or the other can not fulfill their dreams due to Disability. Disabled people are rarely accepted as contributing members of society, and are often seen as a burden to families. Unfortunately data is lacking on many aspects of Disability in the developing world. According to estimates of the United Nations, about $10 \%$ of the world's population is disabled. In developing countries, including Pakistan, disabled people are living a miserable life. It has been estimated that among the 10 million handicapped people in Pakistan, the distribution between urban and rural areas is in the ratio 3:1[1] which may not be true because the statistics on rural areas is not available. Much has been written and said about the disabled people and the privileges they are supposed to get. But it is all in the mind and in newspapers. We do find that some individuals or companies do feel responsibility towards disabled people but we lack regulations to sanction attitudes that scorn and discriminate disabled persons [2]. To understand the phenomenon through this study the researcher wants to explore the status of disabled citizens in Pakistan with focus on Karachi, study the existing system of benefits \& rights and to propose initiatives for the improvements if any for the Disabled people.
\end{abstract}

\section{INTRODUCTION}

It is estimated by the World Health Organization that there are more than 500 million people worldwide who are disabled in some way. Of the total disabled population, 80 percent live in the developing regions of the world -- Africa, Asia, the Caribbean, South and Central America, and the Middle East.

\subsection{Disability: What it is?}

Disability, impairment and handicapped are interrelated and people some times use these terms with same meaning but actually they are different. The following distinctions is made by WHO [3][4] in the context of health experience, among impairment, Disability and handicap:

Any loss of abnormality of psychological, physiological, or anatomical structure or function is known as impairment.

Journal of Independent Studies and Research (JISR) Volume 5, Number2, July 2007
Any restriction or lack (resulting from an impairment) of ability to perform an activity in the manner or within the range considered normal for a human being is known as Disability:

A disadvantage for a given individual, resulting from an impairment or Disability that limits or prevents the fulfillment of a role is known as handicap. Thus, handicap is the loss or limitation of opportunities to take part in the life of the community on an equal level with others.

The two important Models of Disability as described by Sociologist are referenced [5] as under:

\section{The Medical Model of Disability}

- The focus is entirely on the individual and the particular impairment they may have.

- Emphasis on therapeutic cures in an attempt to make the person "whole"

\section{The Social Model of Disability}

- The focus is on organizational and societal barriers, which exist in every facet of day to day life.

- The important issue for the social model to work is to look at ways of breaking down and dismantling barriers.

- It contends that disabled peoples' lack of participation and segregation in society is due to the barriers and not a person's impairment.

\section{INTERNATIONAL MEASURES -RIGHTS \& PRIVILEGES}

Very shortly after its inception, the International Labour Organization took up the question of disabled persons and invalids and where they stood vis-à-vis the world of work. Its first initiative in the field of vocational rehabilitation dates back to 1921, when it explored how the obligation to employ disabled exservicemen and methods of placing disabled persons in employment might be introduced in national legislation. As a result of the conclusions adopted by the experts consulted and the legislative measures that were proposed, the vocational needs of disabled workers gained international recognition for the first time in 1925, when the International Labour Conference adopted a Recommendation on compensation for industrial accidents.

Relegated to the background during the economic depression of the thirties, the question of rehabilitation once again came to the forefront during 
the Second World War with the resurgence of interest in people with disabilities, partly because their numbers had grown as a result of the war and partly because disabled civilians had demonstrated their ability to fill the posts left vacant by mobilized workers, particularly in commerce and industry, to good effect. Thus, the international community deemed it necessary to enshrine in standards to be applied universally, and to implement by concerted action at various levels, the right of disabled persons to benefit from appropriate medical and occupational adaptation and rehabilitation with a view to enjoying social and occupational integration on an equal footing with other members of the community.

In 1944 the International Labour Conference adopted a Recommendation concerning workers with diminished capacity, which affirmed that disabled persons, whatever the origin of their Disability, should be provided with full opportunities for specialized vocational guidance, vocational training, functional and occupational rehabilitation and employment on useful work. However, it was in 1955 that the Conference first discussed the important question of the services to be made available to disabled persons and unanimously adopted the Vocational Rehabilitation (Disabled) Recommendation, 1955.

International Labour Conference, in 1965 and 1968 respectively, focus on the efforts required to widen vocational rehabilitation opportunities for disabled persons

The United Nations General Assembly also adopted a Declaration on the Rights of Mentally Retarded Persons in 1971 and a Declaration on the Rights of Disabled Persons in 1975 (UNCHR 1997-2002),both of which establish the same civil and political rights for mentally retarded or disabled persons as for other people.

In 1975, at one and the same session, the International Labour Conference adopted the Human Resources Development Convention (No. 142), and Recommendation (No. 150), as well as a resolution concerning the vocational rehabilitation and social reintegration of disabled or handicapped persons. From then on the United Nations and the ILO jointly pursued the goal of "full participation and equality". In a resolution adopted on 16 December 1976, the United Nations General Assembly proclaimed 1981 the International Year of Disabled Persons with the theme "full participation" and "equality". A World Programme of Action concerning Disabled Persons was adopted for its implementation. It provided for effective international and national measures to ensure the full participation of disabled persons, on an equal footing with other citizens, in the social life and development of their societies.
United Nations General Assembly proclaimed 198392 the United Nations Decade of Disabled Persons. The three specialized agencies of the United Nations with a mandate to promote the goals of rehabilitation and equalization of opportunities of people with disabilities are the World Health Organization (WHO), the ILO and the United Nations Educational, Scientific and Cultural Organization (UNESCO). These agencies are endeavoring to step up their cooperation in order to promote multisectoral collaboration at the national level for people with disabilities. Numerous activities have been carried out under the aegis of the United Nations as part of the World Programme of Action.

Of particular importance was the adoption by a resolution of the United Nations General Assembly of a set of rules to be observed by governments in order to create the necessary conditions for achieving the objectives laid down in the World Programme of Action. These rules require moral and political commitment on the part of governments, as well as the resolve to undertake the necessary measures.

\section{MAJOR SERVICES \& BENEFITS FOR DISABLED CITIZENS DEVELOPED COUNTRIES}

\section{Japan}

Constitution Guarantees:-Fundamental human rights are secured under the Constitution. Municipal government provides various services-like Medical clinics and welfare centers .1.8 \%ratio for the private sector and $2.0 \%$ for National \& local governments employment is reserved for Disabled Citizens. Special schools are set up for the blind, deaf, and physically handicapped \& retarded. Trains, buses, and aircraft must meet the barrier-free standards The barrier-free building law was enacted in 1994according to which all the Public buildings should be accessible to disabled people. Tax incentives and other financial supports services are provided for the Disabled people.

\section{United Kingdom}

There is mandatory Registration of Disabled persons. Employers of 20 or more people to employ min. of $3 \%$ of disabled persons. Public service vehicles to make them accessible, comfortable, and safe for disabled persons. The Telecommunications service provider not to discriminate service. Use of text phones to be charged for standard price of a voice call . Tariff schemes to compensate disabled persons. 75 $\%$ of the call boxes are accessible to people in wheelchairs. 


\section{USA}

U.S. has addressed disability law in more than 100 laws since 1956. The Social Security Act- provides cash benefits and authorized Medicare for SSI beneficiaries with disabilities. Courts to provide auxiliary aids and services like interpreters, note takers, teletypewriters etc. Electronic and information technology (EIT) services established such as federal websites, telecommunications, software, and information kiosks to facilitate Disabled persons

There is Free Education for All Handicapped Children, Grants and loans are provided to higher education institutions. In 1977, the Tax Reduction and Simplification Act allowed the use of tax credits to promote employment of people with disabilities and encouraging businesses to hire individuals with disabilities. The Federal Advisory Committee Act permits personal assistant services (PAS) for employees with disabilities. Rent subsidy program and direct loans to nonprofit agency projects for persons with mental as well as physical disabilities.

In 1990, the National Affordable Housing Act was passed and established funding authority for supportive housing for Disabled. According to the Architectural Barriers Act of 1968 buildings should be accessible to people with disabilities. There are curb cuts and other features for the safety of people with physical disabilities and to provide accessible rest stops

\section{DISABLED CITIZENS ; LAWS \& SERVICES IN DEVELOPING COUNTRIES}

\section{China}

More than 30 national laws contain specific provisions .According to Election Law a voter, who is not capable to produce a voting card due to his disabilities, may assign someone else. Most local TV programs are broadcast in alternative formats. Standardized Chinese sign language has been developed. There are Braille Libraries in most of the districts. User-friendly pagers, mobile phones and internet-based technologies \& services has been developed for the Disable people

Compulsory free education for children and youth with disabilities.

$1.5 \%$ of job opportunities reserved for persons with disabilities. Tax incentives and financial, technical and other resource assistance are provided.
Government supports welfare enterprises that recruit employees with disabilities and self-employment. State provides vocational education and training. Medical care is at public expense

\section{India}

$3 \%$ of posts must be provided to disabled persons in every establishment. There are $47 \quad$ Special Employment Exchanges and 41 Special Cells in the regular Employment Exchanges. Pre-employment training is provided. Vocational training -imparted in specialized institutions. A number of governmentassisted, private, voluntary organizations, like Amar Jyoti Trust, National Association for the Blind, and the All India Federation of the Deaf, etc. also impart vocational courses.

Appointment of Chief Commissioner for Disabled Persons and Commissioners in each state. In Railways disabled persons get discounts of up to 75 percent. Airlines allow them 50 percent fare discounts. Transmission of Blind Literature packets, both domestic \& foreign, by surface mail is exempt from postage. All Disabled employees of the Central Government get additional transportation allowance of Rs 100. Banks offer loans at a lower rate of interest assisting them to buy homes and start business.

There are National Institutes providing degrees like Bachelor of Education (Deaf) ,Bachelor of Science (Audiology and Speech Pathology, Hearing, Language and Speech), Diploma in Education of the Deaf, Diploma in Communication Disorders etc.

Cost effective Products are developed like speech synthesizer; Braille writing frame; closed-circuit TV with magnification facility; feeding aids for children, multifunctional wheelchair etc.

\section{DISABLED CITIZENS : POSITION WITH REFERENCE TO PAKISTAN}

\subsection{Disable Citizens in Pakistan}

The population of disabled persons in the country calculated according to the WHO criteria of ten percent of the total population came to approximately 14 million at the end of 2002 of whom 7 to 7.5 million are of school age[3]. The disability within the defined population comprised was:

Table1 Disability Prevalence by Province/District -1998 Census [ 9]

\begin{tabular}{l|l|l|l|l|l|l}
$\begin{array}{l}\text { Prov. } \\
\text { District }\end{array}$ & Male & $\mathbf{\%}$ & Female & \% & Total & \% \\
\hline Punjab & $1,073,840$ & 2.8 & 752,783 & 2.1 & $1,826,623$ & 2.5 \\
\hline Prov. Pop. & $38,094,367$ & - & $35,526,923$ & - & $73,621,290$ & - \\
\hline Sindh & 530,600 & 3.3 & 398,800 & 2.8 & 929,400 & 3.1 \\
\hline Prov. Pop. & $16,097,591$ & - & $14,342,302$ & - & $30,439,893$ & -
\end{tabular}

Journal of Independent Studies and Research (JISR)

Volume 5, Number2, July 2007 


\begin{tabular}{l|l|l|l|l|l|l} 
N.W.F.P. & 221,983 & 2.4 & 153,465 & 1.8 & 375,448 & 2.1 \\
\hline Prov. Pop. & $9,084,849$ & - & $8,651,063$ & - & $17,735,912$ & - \\
\hline $\begin{array}{l}\text { Baloach- } \\
\text { chistan }\end{array}$ & 83,420 & 2.4 & 63,001 & 2.1 & 146,421 & 2.2 \\
\hline Prov. Pop. & $3,506,506$ & - & $3,059,379$ & - & $6,565,885$ & - \\
\hline National & Male & $\mathbf{\%}$ & Female & \% & Total & \% \\
\hline $\begin{array}{l}\text { Pop.with } \\
\text { Disabilities }\end{array}$ & $1,918,705$ & 2.8 & $1,373,350$ & 2.2 & $3,292,055$ & 2.5 \\
$\begin{array}{l}\text { Total } \\
\text { Population }\end{array}$ & $68,873,686$ & - & $63,478,593$ & - & $132,352,279$ & -
\end{tabular}

Source: Government of Pakistan, Census Bulletins, 2003, Statistics Division, Islamabad

Table - 1 indicates the incidence of Disability in various Provinces \& districts of Pakistan. It shows $2.8 \%$ of Male and $2.2 \%$ of Female population having Disability.

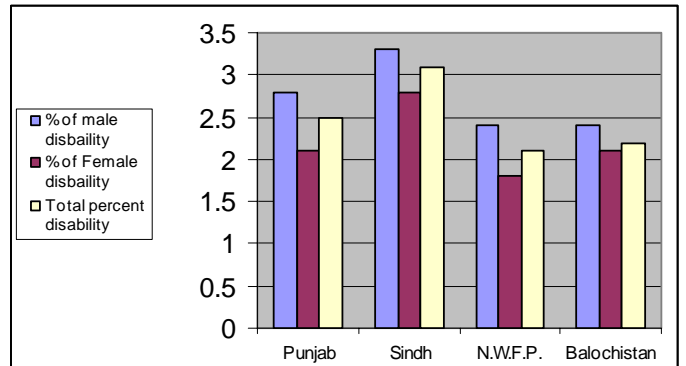

Source: Government of Pakistan, Census Bulletins, 2003, Statistics Division, Islamabad

\section{Figure - 1 Prevalence of Disability by sex, province wise [10]}

The above bar chart (Fig1) indicates prevalence of Disability by sex, province wise, it reflects that there is more Disability prevalence in Males then in females, in all the four provinces of Pakistan. It significantly shows disability to population ratio, where Sindh has the highest and Punjab has the $2^{\text {nd }}$ highest number of Disabled in Pakistan followed by Balochistan and NWFP Province. However if only the number of disabled people are counted then Punjab has more disabled people then any other province.

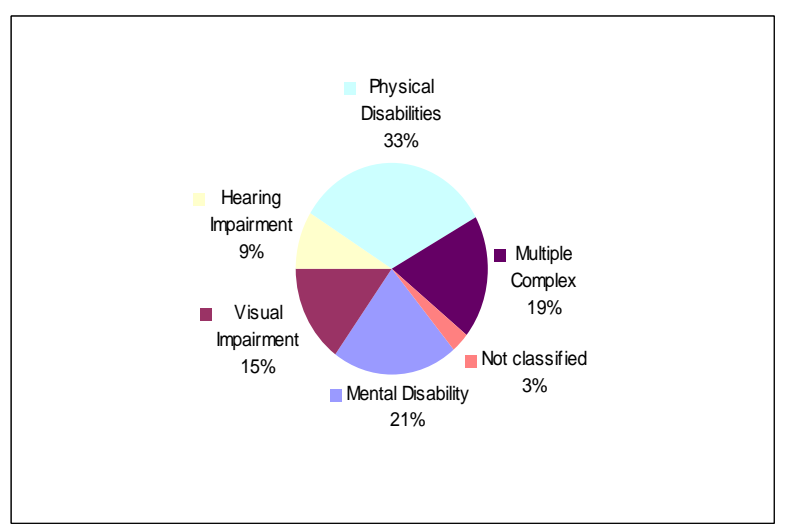

Source : WHO report 2001 Figure2 Types of Disability in population in
Pakistan ( by percentage)

Journal of Independent Studies and Research (JISR) Volume 5, Number2, July 2007

\subsection{Causes of Disability in Pakistan}

As described by Rana \& Fatima [11]in their study (2006) the causes of Disability in Pakistan are numerous and include :

(a) Malnutrition of mothers and children including micro-nutrient deficiency;

(b) Genetic factors;

(c) Prenatal or parental damage;

(d) Infectious diseases (including ear and eye infections);

(e) Other factors: War, Military operations, Earthquakes etc

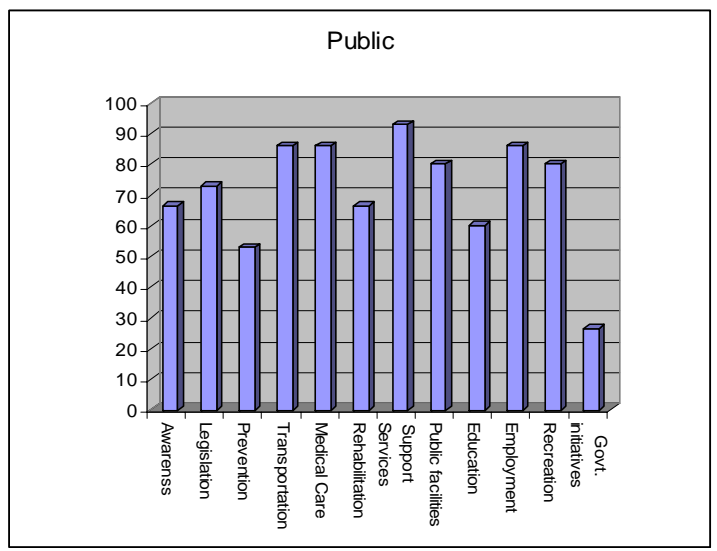

Figure 3 Public Opinion analysis identifying areas of importance (value in percentage)

\subsection{Current Status of Disabled people}

Persons with Disabilities face overwhelming barriers in education, skills development and daily life. Most currently offered services focus on children, with little availability for adult Persons with Disabilities. Persons with disabilities also face multiple social, economic, physical and political handicaps, hampering their freedom of movement in society. There is also a pronounced lack of informational data, rules and regulations, rehabilitation centers, and 
mainstreaming and specialized services for persons with disabilities [12].

In Pakistan, no single Ministry or federal department deals with, issues related to Disability. There is only the Ministry, responsible for social welfare, women's development and special education, which touches upon person with disabilities issues. However, at the local level, there are no specific sections or departments responsible for person with disabilities programs at the local level. Employment opportunities for persons with disabilities are very limited and so they are a financial burden for their families.

\subsection{Common Man \& Disabled Citizens}

In this research we have talked to different categories of people to share their opinion about the disabled citizens who voluntarily shared their views on the issues. Summarizing the answers we find that most of the citizens do realize that that we have to look towards the disabled with sympathy but at the same time we are unable to do anything for them. Moreover we find such disabled exploiting their Disability and are found on streets and begging for money. Public point of view is also that the disabled people have no other alternate but to beg for money to make their living . Others find disabled as unwanted and they feel that they are the one who are least cared by their family hence they have taken to roads and streets. Over all we find that sympathy is shown towards the disabled people and there were issues raised to develop a equitable society for them .

The following chart indicates the public opinion and responses received in which they have suggested as to what areas should be given attention which could ratify life of disabled people.

In Figure 3 , quite significantly we see that option has been expressed regarding requirement of legislation to bring reforms for the disabled citizen. Emphasis has been given to support services, medical education , employment, transportation and public facilities for the disabled.

\subsection{Disabled Citizens View}

While talking to the disabled citizens through informal interview the researcher found them depressing. They painted a gloomy picture and showed their dissatisfaction over the reforms initiated by the government of Pakistan. Critics from this side pointed out about the treatment they have to face from the society and observed that they have no role to play in society. They apprised that no public facilities are provided to them.

They spoke about the hardships in public transport, education, employment, cost of their medical treatment is higher and they have no option to get medicines or treatment through Government sources. Some of the handicapped who are being looked after by their families also complained of the society behaviour.

The one who are supported by their families stated that Inspite of the fact that they are affording or family is looking after their needs they feel that that are out of bond for the society. The educated people who have disabilities view life differently and shown their eagerness to participate and given role in the society matters. They demanded that proper laws be framed which would help reducing chances of discrimination against them.

They voiced that much is needed to be done and strongly recommended support services, transportation, education, employment, medical and public facilities for them and others facing similar situation (Fig-4). It was emphasized by them to create more awareness among masses through media be utilized as resource and legislation is strongly needed.

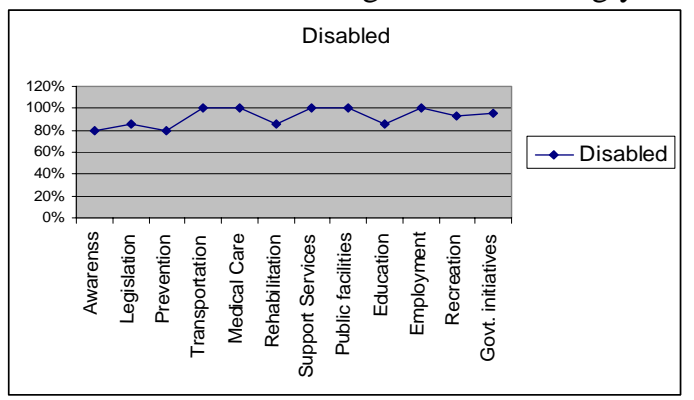

Figure4 Graphical representation indicating areas of reforms identified by Disabled citizens (values in percentage)

\subsection{Government of Pakistan Initiatives}

5.6.1 Legislation: Government of Pakistan promulgated The Disabled Persons (Employment \& Rehabilitation) Ordinance in 1981. Their important characteristic was that accordingly $1 \%$ job quota was reserved for disabled in Govt. Employment [13].

National Council for the Rehabilitation of Disabled Person(NCRDP). The council was established along with its counterparts in each province to ensure the implementation of relevant clauses and undertake all policy decisions aiming at to protect and promote the rights and dignity of Persons with Disabilities.

Government of Pakistan finalized the first ever National Policy for Persons with Disabilities, 2002[14].

Major Areas of Policy focus are:-

o Early Intervention, assessment and medical treatment (Prevention , Detection 
,Intervention ,Counseling ， Counseling ,Family Guidance )

o Education and Training Vocational Training, Employment and Rehabilitation

o Research and Development

o Advocacy and Mass awareness

o Sports and Recreation

o Design of Building, Parks and Public Places

o Institutional Arrangement/ Mechanism (Role of the Federal , Provincial, District Governments and private sector)

\subsection{The Role of NGOs}

There are about 12 International organizations NGO's working for the betterment of the Disabled Citizens in Pakistan: some of them are [15]:

Disability Awareness in Action (DAA)

Disabled Peoples' International (DPI)

Mental Disability Rights International (MDRI)

The World Blind Union (WBU) an Others.

There are some 75 Non-Governmental Organizations working for the disabled citizens in Karachi The NGOs are doing their level best to achieve their targets and goals. They are trying to provide all the facilities but there are areas where they are lacking [11]. Following are the factors that NGOs encountered are:

(a) Insufficient linkages, liaison and co-ordination between the concerned federal and provincial agencies and the policy-formulating and coordinating agency;

(b) Insufficient support from the governmental agencies \& from UN\& other donor agencies

(c) Absence of legal coverage

(d) Resource constraints

(e) Rapid population growth

(f) Insufficient database information of disabled

(g) Insufficient numbers of NGOs

During the survey \& informal interviews, the NGO people supported this survey and appreciated the study being undertaken as it will create more awareness. They provided their responses and allowed free movement in their field offices. Darul Sukoon , NOBEL charitable foundation, Mehmoodabad, Deva school and Anjuman Insaniyat School and rehabilitation center, Malir Karachi are the NGOs visited and interacted with. They guided and identified areas of reforms and shown support for up heal task.

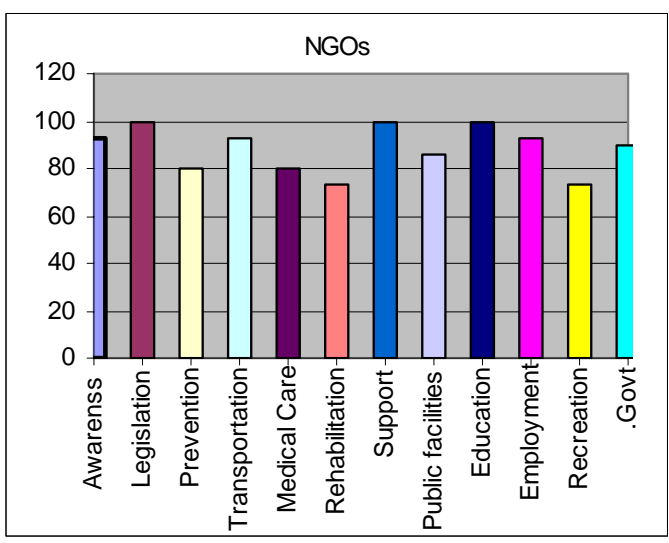

Figure 5 NGO opinion and reform areas

Above Diagram (Fig5) shows the identified areas in bar shape which reflected their opinion. These are areas of concern for the NGOs and hoped that due attention is given for policy formation in the higher offices of the authority.

\section{CONCLUSION}

Ours is a predominantly traditional society. One characteristic of such a society is that majority of its population is fatalistic in its outlook and takes everything under the sun to be 'pre-ordained'. As a result, even known scientific knowledge is not applied to solve problems in the physical and social world, let alone discovering new knowledge. In such a scenario, it is not unsurprising that Disability is considered to be a punishment or God's displeasure.

This research indicates that as per present status disabled citizens are being neglected. Not much has been done to uplift their social status or to provide facilities to them. What ever little done has not been practice or put in implementation. State protection to the underprivileged has been almost negligible. Laws are either silent or absent regarding protection of rights of the Disabled. Other countries viz. the developed counties and the developing counties whose cases have been looked into in this research shows strong adherence to implementation of laws to cover this segment of population so that they can be merged into the main stream of the society. Efforts are made to bring them in the forefront rather to hide them backward. Pakistan needs to revise its laws and rules and to create more space and facilities for its disabled population.

Disability organizations viz. NGOs though trying to fill the gap left by the public sector but not much appears to be in practice. Majority of this work is done in the area of children with disabilities which is also needed but they should not forget the other population age groups. NGOs are shy to progress under the umbrella of Government as they have cumbersome procedure and delays are considered 
routine. Government has to provide support NGOs to come in front and draw policies after due consultation with the disabled and NGO sector. NGOs are also to be blamed. It is their first and foremost duty to keep themselves abreast with changing paradigms about Disability and formulating advocacy campaigns to create awareness amongst the masses [16]. Instead, they primarily focus on service delivery, which is understandable given that the majority of the disabled are the poorest of the poor. However, even their campaigns for policy change have focused largely on 'concessions' in terms of quotas in educational institutions, government jobs and subsidized air fares rather than trying to secure from the state their fundamental right of enabling an equal opportunity environment in all spheres of human life.

There has been a long debate within the Disability movement and among practitioners about what constitutes good practice. Whatever the approach, prevention must be a top priority. This needs to be accompanied with actions which seek to ensure that people with disabilities are supported in their efforts to develop their full potential, and to lead productive and fulfilling lives. As a broad principle, good practice suggests that this means that change must occur within society and in the way it views Disability. Rather than people with disabilities have to change to fit in society. Society must make room for them and uphold their rights.

Based on the above study and facts, analysis, feed back and data appraisal of the literature the following recommendations are proposed:-

$\Rightarrow$ States should assume the ultimate responsibility for the collection of data and dissemination of information on the number of disabled people, types of disabilities, their living conditions etc

$\Rightarrow$ Frame laws and rules for developing a legal framework of protection of rights and providing services to the disabled

$\Rightarrow$ Raise awareness in society about persons with disabilities, their rights, their needs, their potential and their contribution

$\Rightarrow$ A large amount of Disability is preventable, often through relatively simple, low cost interventions. The general improvement of living conditions, improvements to health services will also bring major benefits, both in reducing the risks of Disability and mitigating its effects when it occurs.

$\Rightarrow$ Pubic transport to provide handicapped friendly service

$\Rightarrow$ Free or subsidized medical care services for the Disabled citizens, including hospitalization and, medicines, from the private and government hospitals.

$\Rightarrow$ Provision of rehabilitation services to persons with disabilities in order for them to reach and

Journal of Independent Studies and Research (JISR)

Volume 5, Number2, July 2007 sustain their optimum level of independence and functioning

$\Rightarrow$ Development and supply of support services, including assistive devices for persons with disabilities, to assist them to increase their level of independence in their daily living and to exercise their rights

$\Rightarrow$ For persons with disabilities of any kind, States should (a) introduce programmes of action to make the physical environment accessible; and (b) undertake measures to provide access to information and communication

$\Rightarrow$ Compulsory free education for disabled citizens be introduced. Optimum utilization of information technology to facilitate disabled people.

$\Rightarrow$ Measures to ensure that persons with disabilities have equal opportunities for recreation and sports, Therefore there should be provision of facilities for the disabled in the parks like toilets, walking spaces, sitting areas, parking areas, and other recreational activities be undertaken by the Govt. and the private sector to encourage disabled participation.

\section{REFERENCES}

[1] Sustainable Development Department (SDD), Food \& Agriculture Organization of the United Nations, 2005

[2] Andrew Short, Barrister at Outer Temple Chambers, Legal Services Commission(LSC), Feb. 2006, Rights of Disabled People, Dealing with discrimination, Community legal service, United Kingdom

[3] World Health Organization World Assembly, 2001, Geneva.

[4] World Health Organization. (1976). Document A29/INFDOCI/1, Geneva, Switzerland,

[5] Tensions and Coherence in Disability Policy, DREDF) 2000. The Uneasy Relationship, Lisa Waddington and Matthew Diller . Disability Rights Education and Defense Fund, Inc. , Washington, USA

[6] Revella L. Cook, J.D., Writer-Editor, 2005 , INTERNATIONAL DISABILITY RIGHTS An Overview and Comparative Analysis of International and National Initiatives to Promote and Protect the Rights of Persons with Disabilities, Country reports edited by, Directorate of Legal Research, the Law Library of Congress, Washington 
[7] International Disability Rights Monitor (IDRM) Publications - IDRM Reports Japan ,2003 IDRM Compendium Report

[8] Compendium Report ,UK.USA,China, 2003 IDRM Compendium Report

[9] Government of Pakistan, Census Bulletins, 2003, Statistics Division, Islamabad.

[10] Statistical Yearbook, 2003. Federal Bureau of Statistics, Pakistan

[11]Rana Saba Sultan and Kaneez Fatima Mamdani, 2006. A SOCIOLOGICAL STUDY OF ROLE OF NGOs FOR THE REHABILITATION OF DISABLED CHILDREN, University of Karachi. Pakistan

[12]Country Profileon Disability,Pakistan.Japan International Coperation Agency Report 2003.

[13] Pakistan Country Paper by Mr. Abdul Shakoor Mr. Muhammad Shafi , ( 2-4 June 2003) . Expert Group Meeting and Seminar on an International Convention to Protect and Promote the Rights and Dignity of Persons with Disabilities, Bangkok, Thailand

[14] National Policy for Persons with Disabilities Pakistan, 2002, Monitoring the Implementation of the Biwako Millennium Framework for Action towards an Inclusive, Barrier-free and Right-based Society for Persons with Disabilities in Asia and the Pacific Country Submissions, October 2004, Bangkok, Thailand

[15] Short list of Government Agencies and NonGovernment Organizations, 2002, prepared for Women development Cell, Government of Sindh, Pakistan.

[16] J.M. Camilleri (September, 2003) NGOs and their role in the Disability Sector Lecture Notes/ Presentation 